V.F. Syvokobylenko, V.A. Lysenko

\title{
IMPROVING THE EFFICIENCY OF FAULT PROTECTION SYSTEMS OF ELECTRICAL GRIDS BASED ON ZERO SEQUENCE VOLTAGES AND CURRENTS WAVELET TRANSFORMS
}

Introduction. A significant proportion of earth faults in medium voltage networks represents a short-lived and transient process. Problem. In such cases, earth fault protection that responds to steady-state current and voltage is not able to operate properly. Purpose. To develop earth faults protection selective algorithm using transient components, that occur in zero-sequence currents and voltage in the fault process. Method. A mathematical model of the power supply system was applied to study the transient components of currents and voltage of zero sequence in compensated electrical networks with phase-to-earth faults, and a those model also is used to test the operation of the developed protection algorithm. The results showed that, the reactive power for transient components, of the frequency greater by 4-6 times, than fundamental frequency, which are extracted from the current and voltage of zero sequence by wavelet transform in compensated electrical networks on the damaged feeder, is positive regardless of the degree of compensation of the capacitive current. That may be the basis of the principle of directional protection. Originality. Phase-to-earth fault selective protection algorithm has been developed. In that algorithm, first derivatives of currents and voltages of zero sequence are found, to reduce the influence of aperiodic components. And then, by using of the wavelet transform with Morlet mother function, an orthogonal components are extracted from them. Reactive power is calculated for transient component. If that reactive power excess of threshold, the relay will make a decision. The reliability of the developed protection algorithm is confirmed by the results of mathematical modelling and verification of the test sample at the laboratory stand and by means of field signals that were recorded by digital loggers at the substations. References 10, figures 5.

Key words: electrical grid, earth fault protection, current, voltage, zero sequence, wavelet transform, reactive power.

Для електричних мережс напругою 6-35 кВ, що працюють з компенсованою або ізольованою нейтраллю, розроблено селективний захист від замикань фази на землю, який реагує на напрям реактивної потужності, яка визначається за допомогою коефіцієнтів вейвлет-перетворень струму і напруги нульової послідовності, а також їх похідних, введених для забезпечення фазового зсуву на 90 градусів і підвищення чутливості захисту. Коефіцієнти знаходять иляхом згортки дискретних значень струму, напруги та їх похідних із сигналами материнської функцї̈ Морле, обчислення яких проводиться за допомогою квадратної матриці, для якої викладено правила ї̈ формування. Реактивна потужність визначається на кожному кроці розрахунку як сума добутків вейвлет-коефіцієнтів струму і похідної від напруги, а такожс напруги і похідної від струму, тобто коефіцієнтів, цо мають однаковий порядковий номер. Пуск захисту відбувається за фактом перевищення амплітудою напруги нульової послідовності заданого значення. За допомогою математичної моделі мережі виконано дослідження поведінки захисту за глухих і дугових замикань фази на землю, для різного ступеня компенсації ємнісних струмів, для різних значень напруги в момент замикання. У всіх режимах отримано надійну роботу захисту, чутливість якого в $5-8$ разів перевищує чутливість захисту за алгоритмом, заснованим на перетворенні Фур'є. Бібл. 10, рис. 5.

Ключові слова: електрична мережа, захист від замикань на землю, струм, напруга, нульова послідовність, вейвлетперетворення, реактивна потужність.

Для электрических сетей напряжением 6-35 кВ, работающих с компенсированной или изолированной нейтралью, разработана селективная защита от замыканий фазы на землю, которая реагирует на направление реактивной мощности, определяемое с помощью коэффициентов вейвлет-преобразований тока и напряжения нулевой последовательности, а также их производных, введенных для обеспечения фазового сдвига на 90 градусов и повышения чувствительности защиты. Коэффициенты находят путем свертки дискретных значений тока, напряжения и их производных с сигналами материнской функции Морле, вычисление которых производится с помощью квадратной матрицы, для которой изложены правила ё̈ формирования. Реактивная мощңость определяется на каждом шаге расчета как сумма произведений, совпадающих по фазе и имеющих одинаковый порядковый номер вейвлет-коэффициентов тока и производной от напряэсения, а такэже напряжения и производной от тока. В качестве пускового органа защиты используется превыщение амплитудой напряжения нулевой последовательности заданного значения. С помощьь математической модели сети выполнены исследования поведения защиты при глухих и дуговых замыканиях фазы на землю, при различной степени компенсации емкостных токов, при различных значениях напряжения в момент замыкания. Во всех режимах получена надежная работа защиты, чувствительность которой в $5-8$ раз выше чувствительности защиты, основанной на преобразованиях Фурье. Библ. 10, рис. 5.

Ключевые слова: электрическая сеть, защита от замыканий на землю, ток, напряжение, нулевая последовательность, вейвлет-преобразование, реактивная мощность.

The urgency of the problem and its connection with the applied tasks. In medium voltage power supply systems, damage to the phase insulation leads to singlephase earth faults. In this case, the load current is usually significantly higher than the steady-state earth fault current, which complicates the operation of protection against such faults. Nevertheless, a single-phase earth fault can be extremely dangerous. It can cause fires, damage to electrical equipment as a result of overvoltages or heating by fault current, electric shock to people and animals. According to regulations in force in Ukraine, a section of the electrical grid with a single-phase earth fault must be immediately disconnected if it is located in 
high-risk areas, such as coal mines or enterprises processing fire-hazardous raw materials. The use of a resonantly grounded neutral further complicates the operation of protection devices, as it significantly reduces the already insignificant current of a single-phase earth fault. Another important consequence of a small current of a single-phase earth fault is that such a fault is often unstable, the electric arc at the site of insulation damage can be repeatedly extinguished and ignited again, which gives a single-phase earth fault a permanent transient nature.

Review of publications and shortcomings of known solutions. There is a significant array of sources that investigate the protection of power supply systems against single-phase earth faults. A large number of reviews of publications on the considered problem [1-4] are evidence that the topic of protection against singlephase earth faults today remains a serious challenge for both scientific and theoretical research and engineering and practical developments. In particular, the new methods of signal processing and analysis that have been developed in connection with the development of modern communication systems remain not fully implemented.

Since it is very difficult to obtain information about such a fault from the steady-state current of the zero sequence of the feeder in a single-phase earth fault, much attention is paid to the transient current.

In particular, in [5] it is proposed to use digital filters with infinite pulsed response to extract the information parameter from currents and voltages of zero sequence. In [6], it is proposed to use the Fourier transform to obtain the phase and amplitude characteristics of the voltage and current of zero sequence. In [7], the properties of Fourier transform and wavelet transform are compared on the example of electric arc detection. In [8], it is proposed to detect faults based on the coefficients obtained by wavelet transform. In [9], single-phase faults in a grid with an unearthed neutral are simulated using ATP/EMTP software, and an algorithm for detecting such a fault using wavelet transform is also proposed. But the characteristics of protection algorithms in [7-9] are not considered.

The goal of the paper is to increase the sensitivity and speed of selective protection systems of electrical grids with isolated or compensated neutral based on the use of wavelet transforms of transient components of zero sequence voltages and currents that occur when a phaseto-earth faults occurs during discharge and recharge of grid capacities.

The main material and the results obtained. The study of transients in single-phase earth faults (SEFs) and analysis of the protection operation is performed using a mathematical model, the description of which is given in [10]. Consider a typical two-transformer substation for a $6 \mathrm{kV}$ power supply system, which consists of two $110 / 6 \mathrm{kV}$ step-down power transformers $\mathrm{T} 1$ and $\mathrm{T} 2$, busbars of the first CШ-1 and the second CШ-2 sections, which supply cable lines $\Phi 1-\Phi 3$, on each of which zerosequence current transformers (ZSCTs) are installed. Measuring voltage transformers TH1, TH2 are connected to busbars. The earth fault protection of the phase is connected to the secondary circuits of ZSCTs and THs. The neutral of the grid of the first section is grounded through a reactor with resonant inductance of $0.161 \mathrm{H}$, and the phase capacitances to ground for feeders $\Phi 1-\Phi 3$ connected to this section are 1,8 and $12 \mu \mathrm{F}$, respectively, interphase capacitances are $2 \mu \mathrm{F}$, steady-state earth fault current is $72.3 \mathrm{~A}$. The solution of differential equations in the mathematical model is performed by the implicit method with a calculation step $h=0.667 \mathrm{~ms}$. The calculated values in the simulation are presented in perunit (p.u.) values to the basic:

$$
\begin{aligned}
& U_{b}=\frac{\sqrt{2} \cdot 6000}{\sqrt{3}}=4899 \mathrm{~V} ; \\
& I_{b}=\sqrt{2} \cdot I_{0 f}=\sqrt{2} \cdot 72.36=102.33 \mathrm{~A} ; \\
& Q_{b}=U_{b} \cdot I_{b}=501 \cdot 10^{3} \mathrm{VA},
\end{aligned}
$$

where $U_{b}, I_{b}, Q_{b}$ are the basic voltage, current and power, respectively; $I_{0 f}$ is the single-phase earth fault current.

The frequency [5] and multifrequency [6] protections against SEFs proposed in recent years are based on the use of higher harmonics in currents and voltages that occur in the first moment of the fault and therefore depend on the instantaneous value of the phase voltage on the damaged phase. The degree of distortion of sinusoidal voltages and currents depends on this voltage, which can be seen, for example, from Fig. 1,a,b, which shows the results of modelling the SEF at the initial voltage on the damaged phase, equal to the amplitude one (Fig. 1,a), as well as to zero one (Fig. 1,b). In the first case, there is a fairly long-term coincidence in the phase of current and voltage, while in the second one, the phase coincidence in phase of these signals is much shorter. The sensitivity of the protection algorithm, which is based on the use of the product of these signals, which is proportional to the reactive power, depends on the indicated initial conditions, which must be taken into account when developing new methods of protection.

In 6-35 kV electrical grids operating with neutral isolated or grounded through a Petersen coil, the transients in arc phase-to-ground faults are transient, and therefore there are questions about the correctness of the application of protection algorithms based on the use of frequency [5] and multifrequency [6] components in currents $3 i_{0}$ and voltages $3 u_{0}$ of zero sequence obtained by means of Fourier spectral transforms. For such processes it is more rational to use wavelet transforms (WTs), which allow to decompose the input, time-varying signal $x(t)$ into frequency-time components in the form of coefficients $C W(a, b, t)$ which depend on the selected mother function $g(a, b, t)$ as well as on the coefficients of frequency scale $a$ and time shift $b$ [8]. The study of the characteristics of WTs of currents and voltages and the possibility of using the phase spectrum (phase shift angle) or resistances to build a group protection against phase faults to earth is considered in [1-4]. However, an important task is to develop a stand-alone protection for each feeder, which operates at both arc and steady-state faults, uses the ratio between currents and voltages and has a higher sensitivity. 

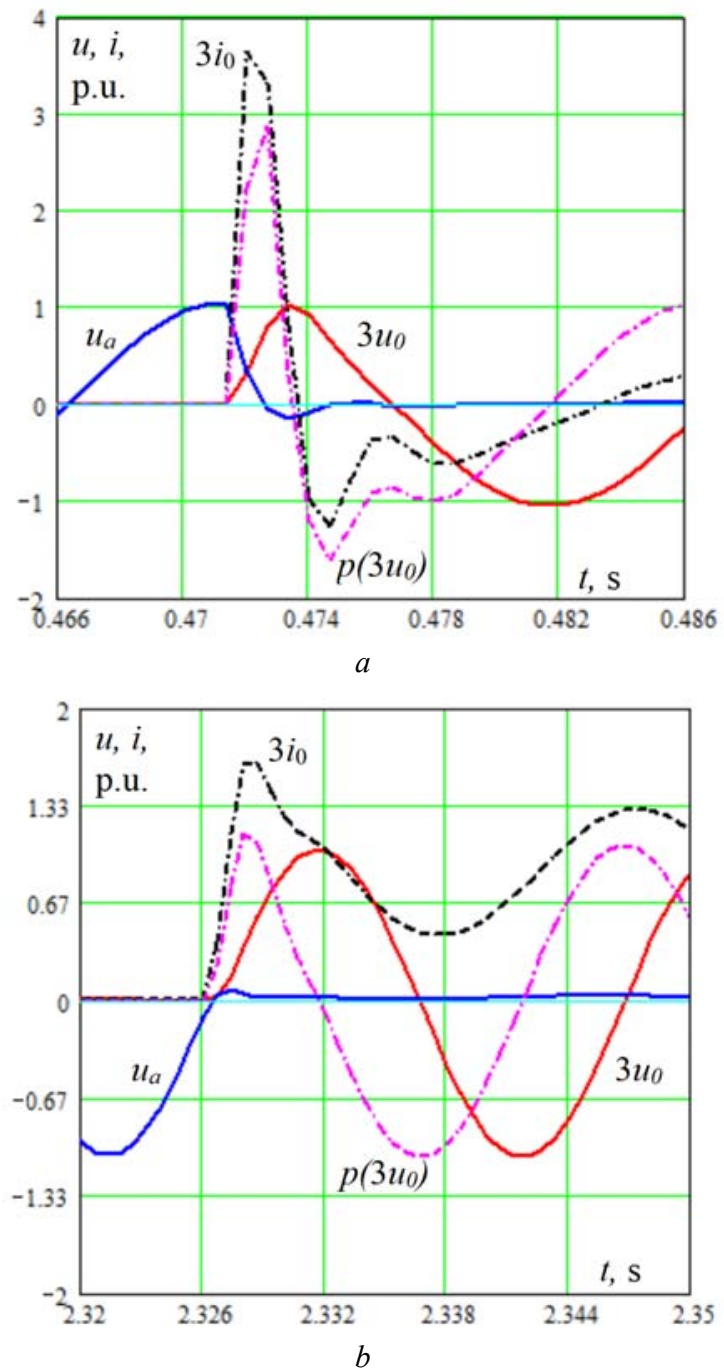

Fig. 1. Results of simulation of SEF which occurred at the maximum $(a)$ and zero $(b)$ instantaneous voltage value on the damaged phase $u_{a}$

As shown in [8], the continuous wavelet transform of signals is performed using an integral expression containing the product of this signal and some basic function called the mother wavelet:

$$
C W(a, b)=\frac{1}{\sqrt{a}} \int_{-\infty}^{\infty} x(t) \cdot g\left(\frac{t-b}{a}\right) d t .
$$

The input signals, in our case, are arrays of dimension $N$, consisting of discrete values of voltages and currents recorded by analog-to-digital converters during the fundamental frequency period $(50 \mathrm{~Hz})$ with discreteness with frequency $f_{s}$, as well as values derived from current $p i=p\left(3 i_{0}\right)$ and voltage $p u=p\left(3 u_{0}\right)$. They are used to compensate the angular phase shift of 90 degrees between the signals of current and voltage of zero sequence (Fig. 1). Numerical determination of derivatives, for example, by three instantaneous values of current (voltage) is performed by expressions that also use the calculation step and the angular frequency $\omega$, which in our case were taken equal respectively $0.667 \mathrm{~ms}$ and $314 \mathrm{~s}^{-1}$

$$
p x=\frac{d x}{d t}=\frac{1}{2 \omega h}\left(3 x_{n}-4 x_{n-1}+x_{n-2}\right) .
$$

As a mother wavelet, we take the complex Morlet wavelet [8], which is a plane wave modulated by the Gaussian curve

$$
g(t)=\exp \left(-\frac{\pi \cdot t^{2}}{2}\right) \cdot \exp (j 2 \pi \cdot t) .
$$

To write (1) and (3) in discrete form, we substitute in (3) instead of time $t$ the expression $(t-b) / a$ which contains the coefficients of frequency scale $a$ and time shift $b$. From the obtained expression we select one of the components of the mother function $g(t)$, for example, imaginary (sine) $g S(n)$. Then the expressions for determining the $k$-th values of the coefficients of wavelet transforms will look like:

$$
\begin{aligned}
& C W(k, a, b)=\frac{1}{\sqrt{a}} \sum_{n=1}^{N} x(k-n) \cdot g\left(\frac{n-b}{a}\right) ; \\
& a=\frac{f_{s}}{f_{n}} ; \quad b=\frac{\pi \cdot a}{2} ; \\
& g S(n)=\operatorname{Im}\left[g\left(\frac{n-b}{a}\right)\right]= \\
& =\exp \left(-\pi \frac{(n-b)^{2}}{a^{2}} \cdot \sin \left(\frac{2 \pi(n-b)}{a}\right)\right) .
\end{aligned}
$$

As an example, Fig. 2 shows the nature of the change of the mother wavelet $g S(n)$ and its amplitude component $J(n)$ at $a=8, b=15, N=30, f_{n}=250 \mathrm{~Hz}$, $f_{s}=1500 \mathrm{~Hz}$. Note that the frequency scale coefficient $a$ is used to set the wavelet duration in the region of the desired frequency range $f_{n}$, the value of which we take equal to $250 \mathrm{~Hz}$, which corresponds to the preferred harmonics at arc faults [6].

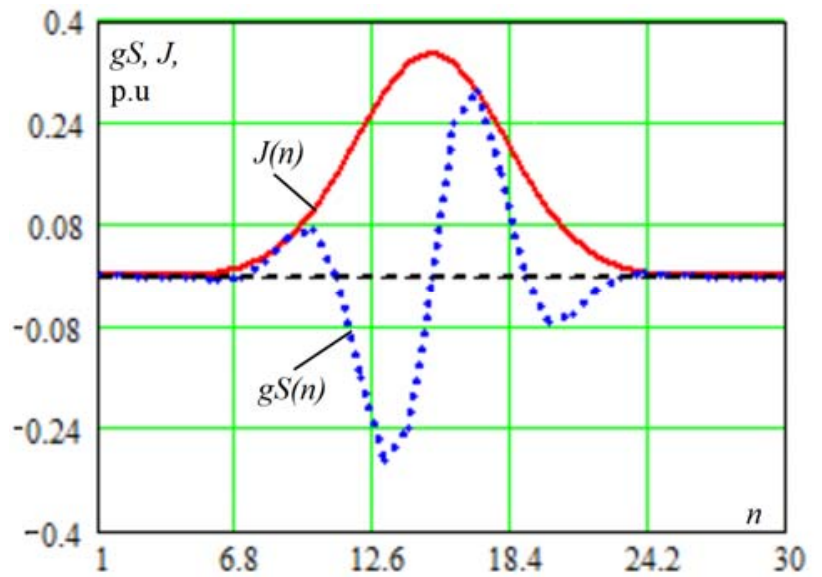

Fig. 2. Nature of the change of the mother wavelet $g S(n)$ and its amplitude $J(n)$

As can be seen from (4), the wavelet transform is a convolution of the values of the input signal (current, voltage and their derivatives) with the same number of values of the mother wavelet function. Here, the convolution is defined as the mutual correlation of one of these sequences with the other one inverse in time. To calculate the convolution, we use the matrix form of representation the inverse in time sequence of values 
calculated by (5) in the case of $n=1, . ., N$. The matrix of the convolution core is a square one with dimension $N \times N$ and on its main diagonal there are the elements $g S_{1}=g S_{(n=1)}$, on the diagonal above the main one $g S_{N-1}=g S_{(n=N-1)}$, then $-g S_{N-2}=g S_{(n=N-2)}$, etc. On the diagonal below the main one there are the elements $g S_{2}=g S_{(n=2)}$, then - accordingly $g S_{3}, \ldots, g S_{N}$. For an array of $N$ elements, the matrix will look like:

$$
\boldsymbol{G}(g S)=\begin{array}{ccccc}
g S_{1} & g S_{N} & g S_{N-1} & \ldots & g S_{2} \\
g S_{2} & g S_{1} & g S_{N} & \ldots & g S_{3} \\
\ldots & g S_{2} & g S_{1} & \ldots & g S_{4} \\
g S_{N} & g S_{N-1} & g S_{N-2} & \ldots & g S_{1}
\end{array}
$$

Vectors of wavelet transforms of voltages $\boldsymbol{W}_{u}$ and currents $\boldsymbol{W}_{i}$ of zero sequence, as well as derivatives of voltages $\boldsymbol{W}_{p u}$ and currents $\boldsymbol{W}_{p i}$ can be found as:

$$
\begin{aligned}
& \boldsymbol{W}_{u}=\boldsymbol{G}(g S) \times \boldsymbol{u} ; \quad \boldsymbol{W}_{i}=\boldsymbol{G}(g S) \times \boldsymbol{i} ; \\
& \boldsymbol{W}_{p u}=\boldsymbol{G}(g S) \times \boldsymbol{p u} ; \quad \boldsymbol{W}_{p i}=\boldsymbol{G}(g S) \times \boldsymbol{p i} .
\end{aligned}
$$

The results of the calculation by expressions (7) of the coefficients of WT with the ordinal number $n=3$ are presented in Fig. 3,a,b, from which it follows that in the initial section of the transient at the SEF there is a close coincidence in phase of the vectors $\boldsymbol{W}_{i}$ and $\boldsymbol{W}_{p u}$, as well as $\boldsymbol{W}_{u}$ and $\boldsymbol{W}_{p i}$. Here, by means of their product for signals with identical serial number it is possible to define value and a sign of reactive power (Fig. 3,a,b). The resulting reactive power $Q$ can be defined as the sum of the products for all $N$ coefficients, which significantly increases the sensitivity of the protection

$$
Q=\sum_{k=1}^{N} W_{u}^{k} \times W_{p i}^{k}-\sum_{k=1}^{N} W_{p u}^{k} \times W_{i}^{k} .
$$

The block diagram of the developed protection algorithm is shown in Fig. 4. It contains analog-to-digital converters (ADCs) to obtain discrete values of voltages $3 u_{0}$ and currents $3 i_{0}$, blocks $d / d t$ to calculate by (2) the derivatives from these signals, the calculation unit for (5) of the mother wavelet function $g(S)$, unit for forming by (6) of the matrix $G(g S)$ of convolution nucleus, units $W_{u}$, $W_{i}, W_{p u}, W_{p i}$ for calculation by (7) of the wavelet transform of voltages, currents and their derivatives, respectively, units of products for calculation by (8) of components of reactive power $Q_{1}=Q_{u p i}=W_{u} \times W_{p i}$ and $Q_{2}=Q_{i p u}=W_{p u} \times W_{i}$, as well as an adder to determine the power $Q=Q_{1}-Q_{2}$, at the exceeding which of the positive threshold value $Q_{t}$ in the comparator, the corresponding signal enters the output relay through a number of logic elements AND, OR. The protection algorithm uses the voltage amplitude exceeding of the threshold value $U_{t}$ as the starting body. The amplitude is determined in the unit $U_{a}$ by its orthogonal components such as $\sqrt{\left(3 u_{0}\right)^{2}+\left(p 3 u_{0}\right)^{2}}$. After the protection has tripped, the relay is self-holding for the duration of its existence $U_{m}>U_{t}$ that provides reliable operation of protection after transition of an arc fault in a steady-state one.
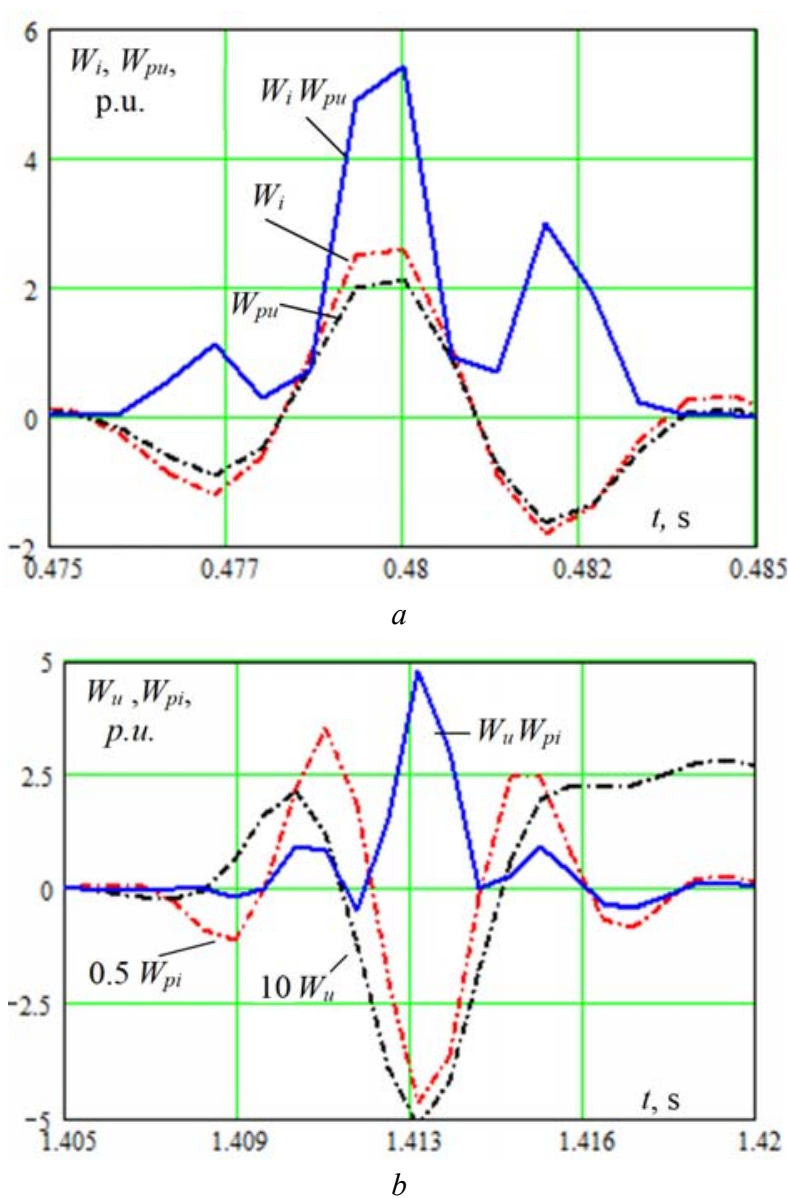

Fig. 3. Coefficients of wavelet transforms of current and voltage derivative $(a)$, current derivative and voltage $(b)$ and the component of reactive power obtained with their help

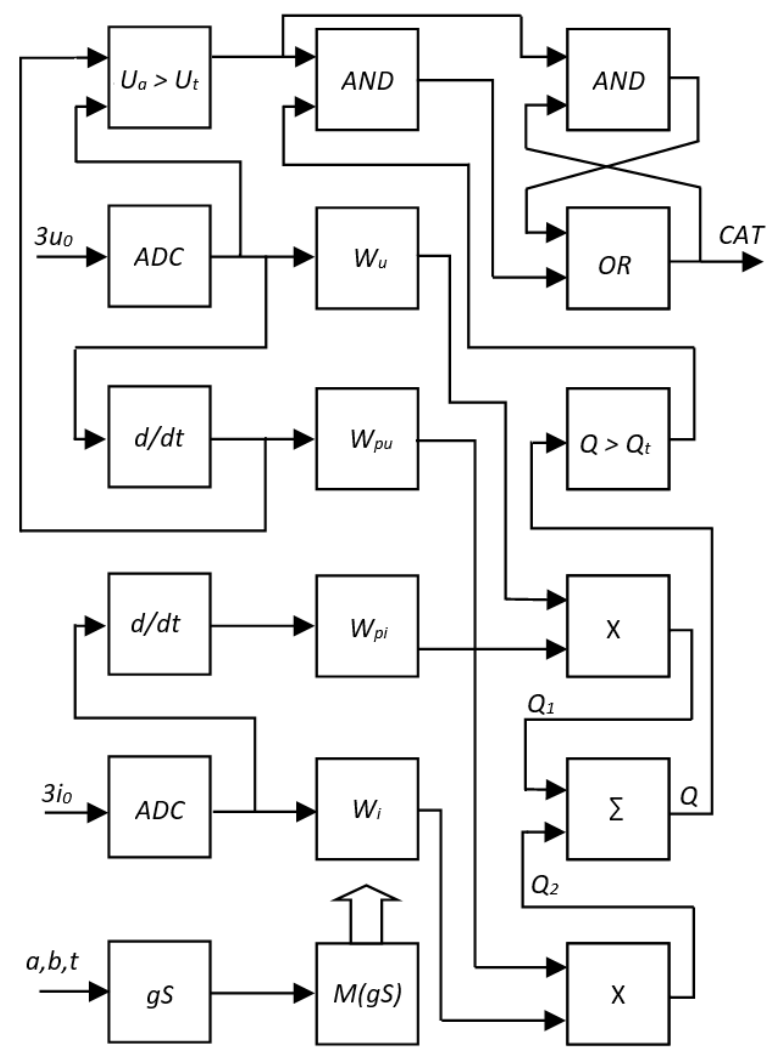

Fig. 4. Block diagram of the «wavelet-protection» algorithm against phase-to-ground fault 
During the development of protection, the issue of increasing its speed by reducing the computational costs of wavelet transform was considered. It is established that for this purpose it is possible to use only fixed values $a=8, b=15$ for calculations by formula (5).

The results of the calculation of the resulting reactive power at the SEF with different initial voltages are shown in Fig. 5. From the given data it follows that the sensitivity of the developed protection in this case is 8 times higher than the sensitivity of the protection built on the basis of Fourier transforms, and the operation time of the protection is about 5-7 ms. The threshold value of reactive power is taken equal to the base value $Q_{b}$.
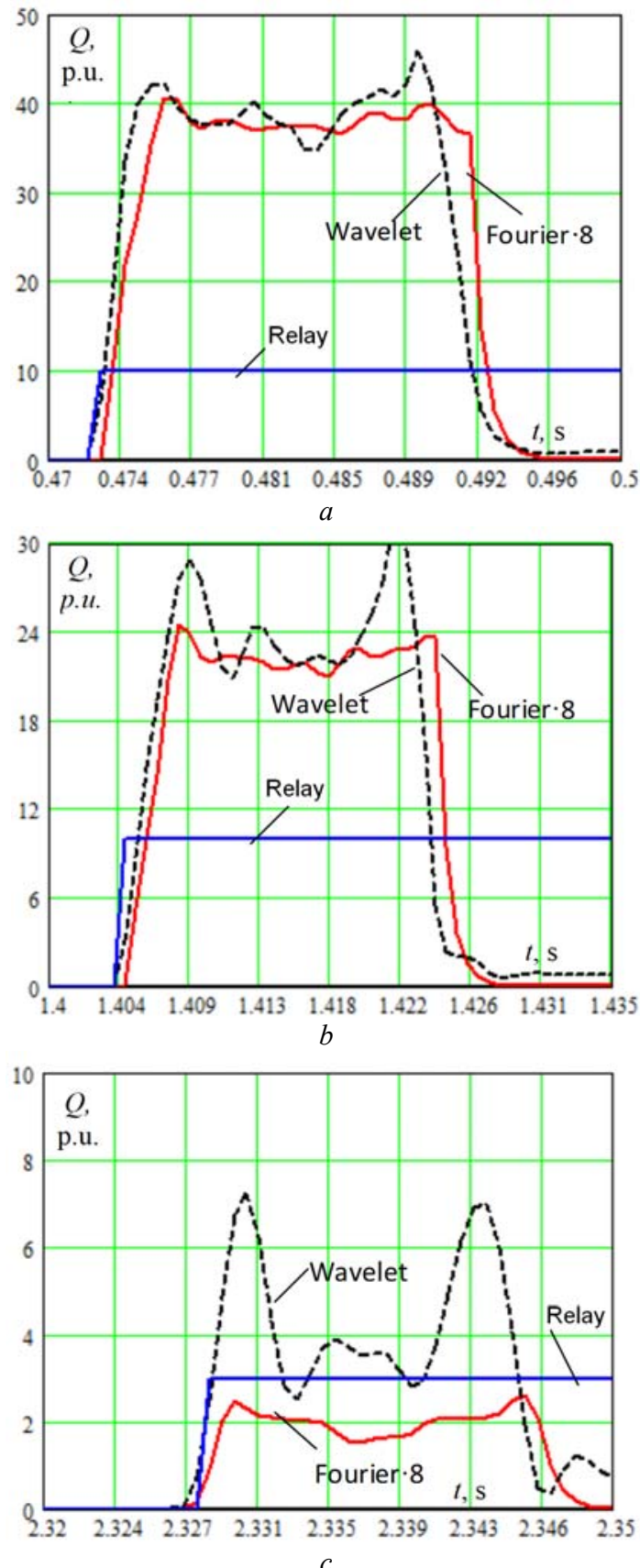

Fig. 5. Reactive power at the SEF determined by wavelet transform and Fourier transform at different initial voltages on the damaged phase:

$u_{\max }(a) ; 0.5 u_{\max }(b) ; 0.01 u_{\max }(c)$
Using a mathematical model, the behavior of protection at different modes of occurrence of SEFs was studied: at resonant tuning of the reactor, over- and undercompensation, at different values of the initial voltage on the damaged phase and different resistances at the fault place. In all these modes there is a clear operation of the output body of the relay.

The lowest sensitivity of protection takes place (Fig. 5,c) at zero initial voltage. Compared to multifrequency protection based on Fourier transform [6], the developed protection has sensitivity almost an order of magnitude higher.

Positive results of protection operation were also obtained when the emergency files of the SEF recorded in the real operation were given to the input, as well as during the tests on the laboratory stand.

\section{Conclusions.}

1. The method of protection of electric grids with isolated or compensated neutral from phase-to-ground faults is improved and a new algorithm of realization of a method on the basis of use of wavelet transforms (WTs) of transient components of voltages and currents of zero sequence is developed that have experimental confirmation and allows to increase the efficiency of operation of electrical grids.

2. Using the coefficients of wavelet transforms, which are found by convolution of discrete values of current, voltage and their derivatives with the signals of the mother Morlet function, the reactive power is calculated, the positive value of which determines the damaged connection.

3. The efficiency of the protection algorithm is confirmed by the results of mathematical modelling and full-scale tests on a laboratory stand.

\section{REFERENCES}

1. Ghaderi A., Ginn H.L., Mohammadpour H.A. High impedance fault detection: A review. Electric Power Systems Research, 2017, vol. 143, pp. 376-388. doi: 10.1016/j.epsr.2016.10.021.

2. Farughian A., Kumpulainen L., Kauhaniemi K. Review of methodologies for earth fault indication and location in compensated and unearthed MV distribution networks. Electric Power Systems Research, 2018, vol. 154, pp. 373-380. doi: 10.1016/j.epsr.2017.09.006.

3. Gururajapathy S.S., Mokhlis H., Illias H.A. Fault location and detection techniques in power distribution systems with distributed generation: A review. Renewable and Sustainable Energy Reviews, 2017, vol. 74, pp. 949-958. doi: 10.1016/j.rser.2017.03.021.

4. Raza A., Benrabah A., Alquthami T., Akmal M. A Review of Fault Diagnosing Methods in Power Transmission Systems. Applied Sciences, 2020, vol. 10, no. 4, p. 1312. doi: 10.3390/app10041312.

5. Syvokobylenko V.F., Lysenko V.A. Earth fault protection for compensated electric networks based on frequency filters. Naukovyi Visnyk Natsionalnoho Hirnychoho Universytetu, 2020, no. 1, pp. 69-74. doi: 10.33271/nvngu/2020-1/069.

6. Syvokobylenko V.F., Lysenko V.A. Multifrequency protecting method against earth-faults of phase in the compensated electric networks. Electrical engineering \& electromechanics, 2020, no. 1, pp. 56-60. doi: 10.20998/2074272X.2020.1.09.

7. Wang Z., McConnell S., Balog R.S., Johnson J. Arc fault signal detection - Fourier transformation vs. wavelet 
decomposition techniques using synthesized data. 2014 IEEE 40th Photovoltaic Specialist Conference (PVSC), 2014, pp. 3239-3244. doi: 10.1109/PVSC.2014.6925625.

8. Michalik M., Rebizant W., Lukowicz M.R., Lee S.-J., Kang S.-H. High-impedance fault detection in distribution networks with use of wavelet-based algorithm. IEEE Transactions on Power Delivery, 2006, vol. 21, no. 4, pp. 1793-1802. doi: 10.1109/TPWRD.2006.874581.

9. Elkalashy N.I., Lehtonen M., Darwish H.A., Taalab A.-M.I., Izzularab M.A. DWT-Based Detection and Transient Power Direction-Based Location of High-Impedance Faults Due to Leaning Trees in Unearthed MV Networks. IEEE Transactions on Power Delivery, 2008, vol. 23, no. 1, pp. 94-101. doi: 10.1109/TPWRD.2007.911168.

10. Syvokobylenko V.F., Lysenko V.A. Mathematical modeling of new algorithms for single-phase earth faults protection in a

How to cite this article:

Syvokobylenko V.F., Lysenko V.A. Improving the efficiency of fault protection systems of electrical grids based on zero sequence voltages and currents wavelet transforms. Electrical engineering \& electromechanics, 2020, no. 4, pp. 67-72. doi: 10.20998/2074-272X.2020.4.09. compensated electrical network. Problemele Energeticii Regionale, 2019, no.1-2(41), pp. 1-11. doi: 10.5281/zenodo.3239135.

Received 01.06.2020

V.F. Syvokobylenko ${ }^{1}$, Doctor of Technical Science, Professor, V.A. Lysenko ${ }^{1}$, Candidate of Technical Science,

${ }^{1}$ Donetsk National Technical University,

2, Shybankova Square, Pokrovsk, Donetsk region, 85300,

Ukraine,

e-mail: svf1934@gmail.com, viktor.lysenko@donntu.edu.ua 